Reprod. Nutr. Dévelop., 1980, 20 (3 A), 593-599.

\title{
On the leakage of acrosomal hyaluronidase from the spermatozoa of the buffalo (Bubalus bubalis)
}

par N. C. GANGULI, S. S. KAKAR

National Dairy Research Institute

Karnal 132001 , India.

Summary. The sonication method produced a quantitatively higher release of buffalo sperm hyaluronidase than the freeze-thaw technique. The released enzyme constituted 10 p. 100 of the total enzymatic activity of the fresh semen. Seminal plasma hyaluronidase activity was not correlated with the motility score of the semen sample.

Unlike cattle semen, the seminal plasma enzyme level in buffalo semen stored at $37^{\circ} \mathrm{C}$ showed a sharp rise, whereas samples stored at $0^{\circ} \mathrm{C}$ evidenced negligible enzyme leakage. Dilution of semen in citric acid whey (CAW) at 5 or $37^{\circ} \mathrm{C}$ significantly prevented the enzyme from leaking into the plasma, although more enzyme was released in extended semen when it was exposed to cold treatments. The enzyme was quite stable in both the seminal plasma and the acrosomal preparations during storage when stored at $5 \mathrm{o}^{\circ} \mathrm{C}$ for prolonged periods.

\section{Introduction.}

Several reports have been published on the release of hyaluronidase from the sperm of various species during storage. Swyer (1947) and Ackerman (1970) examined this release in rabbit and human spermatozoa, respectively. Anand ef al. (1978) and Sidhu and Guraya (1978) studied enzyme release in buffalo spermatozoa under cold treatment. Recently, Ganguli et al. (1973) developed a new extender called « citric acid whey » (CAW) for the storage of buffalo semen. This paper systematically studies the effects on hyaluronidase leakage from the sperm into the seminal plasma when buffalo semen is extended with CAW and stored under different temperatures. Data on buffalo and cattle semen have been compared.

\section{Material and methods.}

Semen samples were collected from Murrah buffalo bulls, and those with a 3.5 to 4.5 motility score were used ( 0 : no motility ; 5 : optimum motility) (Herman and Madden, 1972). Seminal plasma was obtained by centrifuging the semen at $14000 \times \mathrm{g}$ for $30 \mathrm{~min}$ at $4^{\circ} \mathrm{C}$. Extender effect was studied on semen diluted with CAW at the ratio of 1/10 and prepared according to a method described earlier (Ganguli et al., 1973). The total enzyme activity in samples of ejaculated and diluted semen was determined 
by sonication for $5 \mathrm{~min}$ in the cold with a Branson Sonifier (model B-12); the samples were then centrifuged at $14000 \times \mathrm{g}$ for $30 \mathrm{~min}$, and the enzymatic activity of the supernatant was determined.

Storage. - Semen, seminal plasma, acrosomal preparations and extended semen were stored at different temperatures for various periods of time. Samples were taken at given storage intervals. Neat semen was stored up to $8 \mathrm{hrs}$ at 0 to $50^{\circ} \mathrm{C}$, extended semen up to $24 \mathrm{hrs}$ at 5 and $37^{\circ} \mathrm{C}$, and seminal plasma and acrosomal preparation up to 45 days at $5{ }^{\circ} \mathrm{C}$. The hyaluronidase activity of these samples was determined.

Cold shock treatment. - Fresh and extended semens were exposed to cold treatment in the following manner. The samples were kept either in ice for $10 \mathrm{~min}$ or in liquid nitrogen for $2 \mathrm{~min}$ and then immediately brought to $32^{\circ} \mathrm{C}$ in 3 to $5 \mathrm{~min}$ with a warm bath. The other method used was that of Foulkes and Watson (1975) in which spermatozoal enzyme release is obtained by freezing and thawing the samples 5 times. Hyaluronidase activity was determined in the samples before and after cold treatment, as described for seminal plasma.

Hyaluronidase assay. - Hyaluronidase activity in the semen preparation was estimated by a modified method of Rhodes ef al. (1971), based on the determination of the $\mathrm{N}$-acetylglucosamine liberated from the hyaluronic acid by the enzyme. $0.2 \mathrm{ml}$ of $0.05 \mathrm{M}$ citrate buffer, $\mathrm{pH} 4.8$, containing $2 \mathrm{mg}$ of hyaluronic acid per $\mathrm{ml}$ was incubated with $0.1 \mathrm{ml}$ of $1.54 \mathrm{M} \mathrm{NaCl}$ and $0.2 \mathrm{ml}$ of enzyme samples for $30 \mathrm{~min}$ at $37^{\circ} \mathrm{C}$; the reaction was terminated with $0.2 \mathrm{ml}$ of $0.16 \mathrm{M}$ potassium tetraborate. The mixture was heated in a boiling water bath for $3 \mathrm{~min}$ then cooled to room temperature. Three $\mathrm{ml}$ of p-dimethylamine benzaldehyde were added (Reissig ef al., 1955) which, when incubated in a waterbath at $37^{\circ} \mathrm{C}$ for $20 \mathrm{~min}$, developed a color measured according to Reissig et al. (1955). One unit of enzymatic activity was defined as the amount of enzyme causing the release of one $\mu$ mole of $\mathrm{N}$-acetylglucosamine in 30 min at $37^{\circ} \mathrm{C}$. The protein content of the enzyme preparation was estimated according to Lowry ef al. (1951).

Tris, Hyamine 2389, Triton X 100, hyaluronic acid (grade III P), N-acetylglucosamine and p-dimethylamine benzaldehyde were purchased from Sigma Chemical Company, USA. The other chemicals of analytical quality were procured from the local market.

\section{Results and discussion.}

A. Total hyaluronidase activity in buffalo semen. - In order to express the release of sperm hyaluronidase into the seminal plasma as a percentage of the total enzymatic activity in the semen, it was necessary to quantitatively estimate the total enzymatic (seminal plasma enzyme acrosomal enzyme) activity. We adopted two procedures, namely (i) the freeze-thaw method of Foulkes and Watson (1975) and (ii) the sonication method of Kaur et al. (1976). The sonication method gave a much higher value for the seminal plasma enzyme $(16.60$ units $/ \mathrm{ml})$, which was almost 3.34 -fold more than the values obtained $(4.97$ units $/ \mathrm{ml}$ ) by the freeze-thawing method (table 1 ). When sonication was used on cattle semen, a higher enzyme release ( 3.2 -fold more) 
was observed. This indicated that the cold-shock method did not rupture the sperm membrane enough to permit complete leakage of the acrosomal enzyme into the plasma.

TABLE 1

Total hyaluronidase activity in semen

\begin{tabular}{|c|c|c|c|c|}
\hline \multirow{3}{*}{ Treatment } & \multicolumn{4}{|c|}{$\begin{array}{c}\text { Hyaluronidase activity } \\
\text { units } / \mathrm{ml}\end{array}$} \\
\hline & \multirow{2}{*}{$\begin{array}{l}\text { Buffalo } \\
\text { (B) }\end{array}$} & \multirow{2}{*}{$\begin{array}{c}\text { Cattle } \\
\text { (C) }\end{array}$} & \multicolumn{2}{|c|}{$\begin{array}{l}\text { Fold increase } \\
\text { in plasma }\end{array}$} \\
\hline & & & B & $C$ \\
\hline $\begin{array}{l}\text { Original seminal plasma... } \\
\text { Freeze-thaw method....... } \\
\text { Sonication method........ }\end{array}$ & $\begin{array}{r}1,98 \\
4.97 \\
16.60\end{array}$ & $\begin{array}{r}2.32 \\
6.22 \\
20.08\end{array}$ & $\begin{array}{l}\overline{2.5} \\
8.3\end{array}$ & $\begin{array}{l}-\overline{2.6} \\
8.6\end{array}$ \\
\hline
\end{tabular}

The total hyaluronidase activity (expressed per $\mathrm{ml}$ ) in buffalo semen was less $(16.60$ units $/ \mathrm{ml})$ than in cattle semen $(20.0$ units $/ \mathrm{ml}) *$. However, if the sperm population per ejaculate is considered, the enzyme value of buffalo semen is higher since cattle semen has a much greater concentration of spermatozoa per ejaculate (Bhattacharya, 1974). This demonstrates that buffalo spermatozoa have a higher hyaluronidase level than cattle spermatozoa, and it would suggest that the problem encountered in buffalo breeding might not be due to a lack of this hydrolase in the acrosome (Allison and Hartree, 1970), but to its faster leakage.

B. Hyaluronidase activity in seminal plasma as related to sperm motility. - The results in table 2 show that seminal plasma hyaluronidase levels have no apparent correlation with the motility score of the semen sample. The mean value obtained was 1.57 units/ml, which represented about 9 p. 100 of the total enzymatic activity in buffalo semen. Kaur ef al. (1976) also reported a similar value for this enzyme in buffalo seminal plasma, whereas in cattle semen the initial value was about 11 p. 100 of the total enzymatic activity (Foulkes and Watson, 1975 ; Ganguli and Kakar, 1979).

The total hyaluronidase activity in buffalo semen was 16.6 units $/ \mathrm{ml}$ (determined by sonication) which was lower than in cattle semen $(20.0$ units $/ \mathrm{ml}$ ) (Ganguli and Kakar 1979). This might be due to the lower concentration of spermatozoa in buffalo semen (Bhattacharya, 1974).

C. Hyaluronidase release in neat and extended semens during storage at different temperatures. - The release of spermatozoal hyaluronidase in the extracellular fluid of semen stored at 0,37 and $50^{\circ} \mathrm{C}$ for an $8 \mathrm{hr}$ period is shown in figure 1 . The released enzyme activity was expressed as a percentage of the increase over the initial value of 1.5 units $/ \mathrm{ml}$ of seminal plasma enzyme. Semen stored at $37^{\circ} \mathrm{C}$ evidenced a sharp

* Both the treatments (freeze-thaw and sonication) resulted in a similar release of the enzyme, as evidenced by the increased enzymatic activity in the seminal plasma. 
TABLE 2

Hyaluronidase activity in buffalo seminal plasma

\begin{tabular}{ccc}
\hline \multirow{2}{*}{$\begin{array}{c}\text { Motility } \\
\text { score }\end{array}$} & \multicolumn{2}{c}{ Hyaluronidase activity } \\
\cline { 2 - 3 } & Seminal plasma & $\begin{array}{c}\text { Percent of } \\
\text { total activity }\end{array}$ \\
\hline $0-0.5$ & $1.606 \pm 0.32$ & 9.6 \\
$0.5-1$ & $\begin{array}{c}1.516 \pm 0.48 \\
(35)\end{array}$ & 9.1 \\
$0-1$ & $1.695 \frac{(4)}{(8)} 0.29$ & 10.2 \\
$2-3$ & $1.596 \pm 0.304$ & 9.6 \\
$3-5$ & $1.443 \pm 0.29$ & 8.6 \\
Mean $\ldots .$. & $1.571 \pm 0.09$ & 9.4 \\
\hline
\end{tabular}

* Figure in parantheses indicate the number of replicates.

** The total enzyme activity represents the value in the semen sample after sonication (see text) and accounts for both initial plasma enzyme and released enzyme into the seminal plasma from fresh semen samples on sonication.

increase of 104.4 p. 100 (fig. 1B), whereas at $0^{\circ} \mathrm{C}$ (fig. $1 \mathrm{~A}$ ) there was no significant release. At $50^{\circ} \mathrm{C}$ the release was also less (fig. 1D) ; this could be due to enzyme inactivation at that temperature (Yang and Srivastava, 1975). Masaki and Hartree (1962) also observed that when normal cattle semen was stored, the hyaluronidase diffused from the spermatozoa to the seminal plasma. Interestingly enough, cattle semen stored in similar conditions exhibited only a 35 p. 100 increase in the enzymatic activity of the extracellular fluid (fig. 1C). These data therefore show that buffalo sperm suffered higher cell damage at $37^{\circ} \mathrm{C}$ than cattle sperm. As hyaluronidase is the most readily released spermatozoal enzyme (McRorie and Williams, 1974), these findings are being exploited in our laboratory for monitoring buffalo semen quality.

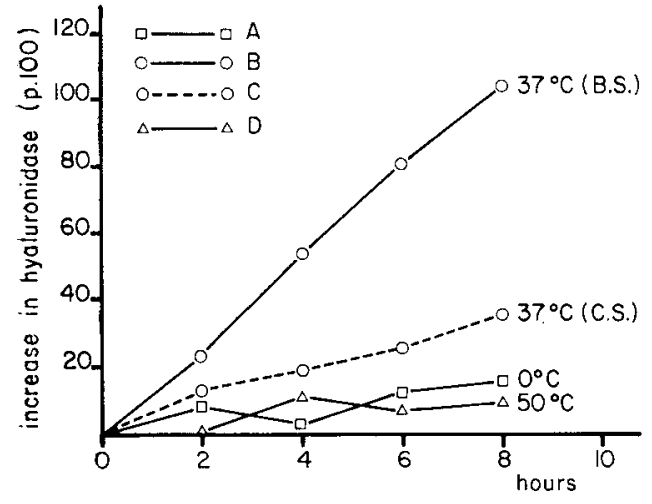

FIG. 1. - Extracellular release of hyaluronidase in buffalo and cattle semen on storage at different temperature. B. S. : Buffalo semen, C. S. : Cattle semen, A, B, C and $D$ : Semen samples stored at $0^{\circ}$, $37^{\circ} \mathrm{C}$ (B. S.), $37^{\circ} \mathrm{C}$ (C. S.) and $50^{\circ} \mathrm{C}$, respectively. 
D. Effect of cold-shock and deep-freezing on hyaluronidase release in neat and extended semens.

Change in neat semen enzyme level. - Chinnaiya and Ganguli (1978) have recently reported a significant decrease of 30 p. 100 in buffalo spermatozoal motility when the semen was exposed to an ice-water bath $\left(4^{\circ} \mathrm{C}\right)$ for $10 \mathrm{~min}$. Hence, the level of extracellular hyaluronidase activity in buffalo semen, exposed to different types of cold treatments, offers indirect but valuable data on acrosomal integrity. The results in table 3 show that the extent of spermatozoal enzyme release depends on the type of cold-shock used on the semen. Considering the enzymatic activity in the sonicated semen as 100 , the frozen-thawed samples gave a maximum enzyme release of about 30 p. 100 . The freezing technique for buffalo semen is now being standardized by perfecting the steps of freezing and glycerolization (Chinnaiya, 1978).

TABLE 3

Extracellular hyaluronidase activity in semen on cold shock treatment

\begin{tabular}{|c|c|c|c|c|}
\hline \multirow[t]{2}{*}{ Cold shock treatment } & \multicolumn{2}{|c|}{$\begin{array}{c}\text { Hyaluronidase activity } \\
\text { in seminal plasma } \\
\text { (units } / \mathrm{ml} \text { ) }\end{array}$} & \multicolumn{2}{|c|}{$\begin{array}{c}\text { Percent of } \\
\text { total }\end{array}$} \\
\hline & $\begin{array}{l}\text { Fresh semen } \\
\text { (FS) }\end{array}$ & $\begin{array}{l}\text { Extended semen } \\
\text { (ES) }\end{array}$ & FS & ES \\
\hline 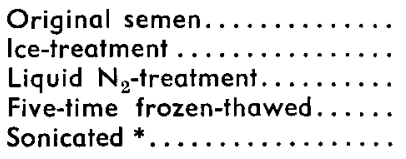 & $\begin{array}{l}1.98 \pm 0.57 \\
2.53 \pm 0.38 \\
3.10 \pm 0.24 \\
4.97 \pm 2.5 \\
16.60 \pm 6.6\end{array}$ & $\begin{array}{l}0.218 \pm 0.26 \\
0.326 \pm 0.26 \\
0.684 \pm 0.30 \\
0.736 \pm 0.47 \\
1.18 \pm 0.43\end{array}$ & $\begin{array}{l}11.9 \\
15.2 \\
18.6 \\
29.9 \\
100\end{array}$ & $\begin{array}{r}18.4 \\
27.6 \\
57.9 \\
62.3 \\
100\end{array}$ \\
\hline
\end{tabular}

* The HA in seminal plasma of sonicated semen samples was taken as 100.

Change in extended semen enzyme level. - Buffalo semen extended in CAW was exposed to similar cold treatments as above. The results in table 3 show that seminal plasma hyaluronidase level increased with all the treatments. Considering the sonicated semen as 100 , more enzyme was released as compared to fresh semen. Freeze-thaw and liquid nitrogen appeared to cause a similar rate of enzyme release (about 60 p. 100). Although CAW was efficient in preserving the cytomorphological characteristics of buffalo spermatozoa when stored at $5{ }^{\circ} \mathrm{C}$ (Reddy and Mukherjee, 1976), cold-shock treatments appeared to induce enzyme release in that semen. On the other hand, Chinnaiya, Kakar and Ganguli (1979) observed a lower sperm release of other enzymes like GOT and GPT in post-freeze samples of CAW-extended buffalo semen as compared to EYC and TRIS-extended samples. The subsequent cooling procedure and the addition of the glycerol-containing fraction of the diluent did not significantly modify hyaluronidase release during semen freezing.

E. Extracellular hyaluronidase in buffalo semen extended with CAW. - Several reports from our laboratory (Ganguli ef al., 1973 ; Bhosrekar and Ganguli, 1976) have established that buffalo semen can be successfully extended with CAW both for cold 
storage and for freezing (Chinnaiya, 1978). The rate of acrosomal enzyme leakage into the seminal plasma in buffalo semen extended with CAW is therefore being estimated. It is clear from the results of figure 2 that the hyaluronidase level in the extracellular fluid was almost unchanged when the semen was stored in CAW at 5 or $37^{\circ} \mathrm{C}$ for the period studied (12 hrs). This establishes the efficiency of CAW as a suitable diluent for protecting the acrosome, even at $37^{\circ} \mathrm{C}$ (15 trials) ; neat semen at that temperature showed a 100 p. 100 release of that acrosomal enzyme as compared to the initial level (fig. 1).

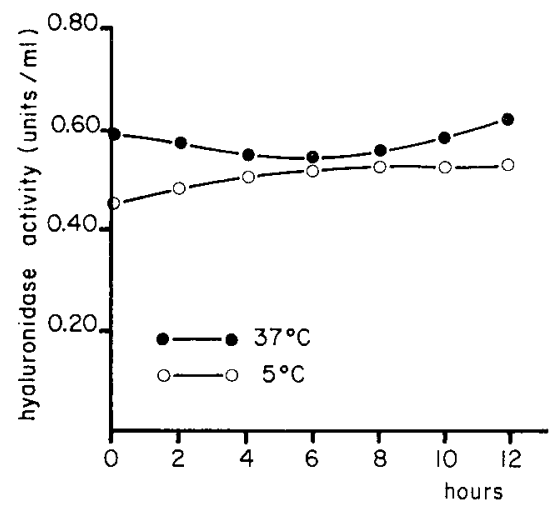

FIG. 2. - Release of hyaluronidase in buffalo semen extended in CAW during storage at $5{ }^{\circ} \mathrm{C}$ and $37^{\circ} \mathrm{C}$.

F. Hyaluronidase activity in seminal plasma and acrosomal preparation after storage. - Seminal plasma and acrosomal preparations were stored in the cold $\left(5^{\circ} \mathrm{C}\right)$, at room temperature $\left(30^{\circ} \mathrm{C}\right)$ or in a frozen condition $\left(-15^{\circ} \mathrm{C}\right)$ to determine hyaluronidase stability. The enzyme was more stable in seminal plasma than in the acrosomal preparation in all these conditions. Storage temperature had very little effect on the enzyme.

\section{Conclusion.}

The hyaluronidase activity of buffalo semen seminal plasma is not correlated with the mass activity of neat semen. This semen stored at $37^{\circ} \mathrm{C}$ shows a high rate of acrosomal hyaluronidase release, contrary to the semen extended with CAW. The sonication technique appears to be a better method for quantitative hyaluronidase release from the spermatozoal acrosome.

Reçu en mai 1979.

Accepté en oout 1979.

Acknowledgements. - The authors are grateful to Dr. D. Sundaresan, Director, for his constant encouragement. The technical assistance of $\mathrm{Mr}$ B. M. Sharma is acknowledged.

Résumé. La désintégration par ultrasons entraîne une décharge plus importante de la hyaluronidase du sperme de buffle que la congélation/décongélation. La fraction perdue constifue 10 p. 100 de l'activité enzymatique totale du sperme frais. Nous n'avons pu trouver de rapport entre l'activité de la hyaluronidase du plasma séminal et la motilité du sperme. 
A la différence des Bovins, l'activité enzymatique trouvée dans le plasma séminal de buffle conservé à $37^{\circ} \mathrm{C}$ présente une augmentation marquée, alors qu'à $0{ }^{\circ} \mathrm{C}$ la perte d'enzyme est négligeable. La dilution du sperme dans le milieu acide citrique-petit lait à 5 ou $37^{\circ} \mathrm{C}$ empêche significativement la fuite de l'enzyme dans le plasma, bien que la quantité d'enzyme libérée soit plus importante lorsque le sperme dilué est conservé au frais. L'enzyme est parfaitement stable dans le plasma séminal et les préparations acrosomiques au cours de conservation à $50^{\circ} \mathrm{C}$ pendant de longues périodes.

\section{References}

ACKERMAN D. R., 1970. Hyaluronidase in human semen and sperm suspension subjected to temperature shock and to freezing. J. Reprod. Fert., 23, 521-523.

ALLISON A. C., HARTREE E. F., 1970. Lysosomal enzymes in the acrosome and their possible role in fertilization. J. Reprod. Fert., 21, 501-515.

ANAND S. R., KAUR S. P., CHAUDHRY P. S., 1978. Release of hyaluronoglucosiminidase, -Nacetyl glucosiminidase, acid and alkaline phosphatase from buffalo spermatozoa during preservation. Indian J. exp. Biol., 16, 286-288.

BHATTACHARYA P., 1974. Reproduction, 105-108. In COCKRILL W. R., The husbandry and health of the domestic buffalo, FAO Rome.

BHOSREKAR M., GANGULI N. C., 1976. Preservation characteristics of buffalo semen in citric acid whey as an extender. J. Reprod. Fert., 48, 215-216.

CHINNAIYA G. P., 1978. Studies on the freezability of buffalo semen in different extenders. Ph. D. Thes., Kurukshetra Univ.

CHINNAIYA G. P., GANGULI N. C., 1978. Cold shock and resistance test in evaluating buffalo semen. Indian J. Dairy Sci., 31, 284-286.

CHINNAIYA G. P., KAKAR S. S., GANGULI N. C., 1979. Extracellular release of transaminases from buffalo spermatozoa on freezing of semen in extenders. Z $b l$. Vet. Med. A (in press).

FOULKES J. A., WATSON P. A. 1975. Hyaluronidase activity in seminal plasma as a method of assessing bull sperm integrity. J. Reprod. Fert. 43, 349-353.

GANGULI N. C., BHOSREKAR M., STEPHAN J., 1973. Milk whey as a diluent for buffalo semen. J. Reprod. Fert., 35, 355-358.

GANGULI N. C., KAKAR S. S., 1979. Zbl. Vet. Med. A (in press).

HERMAN H. A., MADDEN F. W., 1972. The artificial insemination of dairy and beef cattle. A handbook and laboratory manual. 4th Edn., Lucas Brothers Pub. Columbia, MO.

KAUR S. P., CHAUDHRY P. S., ANAND S. R., 1976. Acrosomal Hydrolases in buffalo spermatozoa. Experientia, 32, 436-438.

LOWRY O. H., ROSEBROUGH N. J., FARR, A. L., RANDALL R. J., 1951. Protein measurement with the Folin Phenol reagent. J. biol. Chem., 193, 265-275.

MASAKI J., HARTREE E. F., 1962. Distribution of Metabolic activity, phospholipids and hyaluronidase between the heads and tails of bull spermatozoa. Biochem. J., 84, 347-353.

MCRORIE R. A., WILLIAMS W. L., 1974. Biochemistry of mammalian fertilization. Annual Rev., Biochem., 43, 777-803.

REDDY A. O., MUKHERJEE D. P., 1976. Effect of egg-yolk-glucose citrale and citric acid whey diluents on the dimensional characteristics and proportions of live spermatozoa of buffaloes. Indian J. Anim. Sci., 46, 279-282.

REISSIG J. L., STROMINGER J. L., LELOIR L. F., 1955. A modified colorimetric method for the estimation of $\mathrm{N}$-acetylamino sugars. J. biol. Chem., 217, 959-966.

RHODES C., DUDGSON K. S., OLAVESEN A. H., HOGBERG B., 1971. Unsuitability of indoxyl acefate as a substrate for the assay of testicular hyaluronidase. Biochem. J., 122, 575-582.

SIDHU K. S., GURAYA S. S., 1978. Effect of cold shock on release of enzymes in buffalo spermatozoa. Ann. Biol. anim. Bioch. Biophys., 18, 283-286.

SWYER G. I. M., 1947. The release of hyaluronidase from spermatozoa. Biochem. J., 41, 413-417.

YANG C. H., SRIVASTAVA P. N., 1975. Purification and properties of hyaluronidase from bull sperm. J. biol. Chem., 250, 79-83. 